\title{
Efficiency of pulverizing aeration on Lake Panieńskie
}

\author{
Ewa Osuch, Stanisław Podsiadłowski \\ Institute of Biosystem Engineering, Poznań University of Life Sciences, Wojska Polskiego 50, 60-637 Poznań, Poland, \\ e-mail: ewa.kaczorowska@up.poznan.pl, stapod@up.poznan.pl
}

\begin{abstract}
The principal threat to lakes of the temperate zone is posed by factors accelerating their eutrophication and causing marked deoxygenation of the deeper layers of water, mainly the hypo- and metalimnion. Among their effects are frequent phytoplankton blooms, including those of blue-green algae, and general deterioration of water quality also affecting the abundance and health status of fish. The chief concern is a disturbed proportion between the quantity of complex chemical compounds, especially organic, and the oxygen content of lake waters. Natural processes of water oxygenation are not too intensive, because they are practically limited to the epilimnion layer, connected as they are with the activity of aquatic plants of the littoral and sublittoral zone (which tends to disappear in contaminated lakes) and wind energy (the effect of waving). In summer conditions, with a relatively great chemical activity of bottom deposits, the intensity of those processes is usually inadequate. Hence, in 1995 research was launched in the Institute of Agricultural Engineering of the Agricultural University in Poznan on an integrated lake restoration technology whose core was a self-powered aerator capable of oxygenating also the bottom layers of water (the hypolimnion) of deep lakes. The aerator uses energy obtained from a Savonius rotor mainly to diffuse gases: to release hydrogen sulphide, which usually saturates the hypolimnion water completely, and then to saturate this water with oxygen. Even early studies showed the constructed device to be highly efficient in improving oxygen conditions in the bottom zone. They also made it clear that it should be equipped with an autonomous system designed to inactivate phosphorus, one of the principal factors determining the rate of lake degradation. In 2003 the first wind-driven pulverizing aerator equipped with such a system was installed in Lake Urban in Chodzież. The aim of this work is to present the principles of operation of a wind-driven pulverizing aerator with a phosphorus inactivation system, as well as its general technical characteristics and preliminary results of a study of its performance.
\end{abstract}

Key words: lake restoration, eutrofication, aeration

\section{Introduction}

According to Soszka et al. (2003), approximately $3.8 \%$ of Polish lakes can be labelled as firstclass waters. The majority of our lakes are second-class (36.6\%) and third-class water bodies (38.9\%), whereas unclassified water bodies constitute as much as $20 \%$. A significant deterioration in lake cleanness took place around thirty years ago. This was a result of the development of agriculture, where its chemization as well as the development of tourism and local industry turned out to be the most detrimental.

The main threat to the temperate zone lakes is factors that precipitate eutrophication and trigger considerable deoxidization of deeper layers of water, the hypolimnion and metalimnion mainly. This results in phytoplankton bloom and general deteriora- tion in water quality, which also affects the frequency and health of fish. The main point here is to maintain proportions between the number of complex compounds (especially organic ones) and the amount of oxygen contained in lake water.

Natural processes of water oxygenation are not too intense since they are basically constrained to the epilimnion. Low intensity of oxygenation is especially caused by water vegetation activity in the littoral and sublittoral zones (which disappears in contaminated lakes) and by wind power (the so-called waving effect). In summer conditions, along with the comparatively high chemical activity of lakebed deposits, the intensity of these processes is more often than not clearly insufficient.

Oxygenation of the hypolimnion waters is one of the basic methods of lake rehabilitation. It is most 
often carried out with the use of aerators, which allow the problem to be resolved where it occurs (Lossow et al. 1998). In the case of the application of this method, neither contaminated lake waters nor lakebed deposits undergo translocation. Initially, aerators were mainly employed in sewage plants, yet the increasing problem of lake eutrophication exacted the application of such constructions also in open waters after all. On the basis of the principle of work, aerators can be divided into two basic groups (Fig. 1) i.e. pulverizing aerators and pneumatic aerators (Podsiadłowski 2001).

Pneumatic aerators are devices that pump air into the water layer that is being oxygenated. The main drawback of these devices is that they are characterized by considerable energy consumption and comparatively low effectiveness, which are hard to accept even today. In this system, the air is pumped into the water layer which is already saturated with hydrogen sulphide or methane.

Pulverizing aerators, in turn, are devices which spray water into the air. The most simple of these do not require provision of outside energy: they employ the waterfall effect, which is observed in nature, exploiting the kinetic energy of flowing water to be exact. In the case of sewage plants and fish ponds mechanical splash aerators are powered with electrical energy, whereas in the case of lakes, they are powered with wind energy. An important advantage of such aerators is spraying water into atmospheric air, thus in the conditions of its superabundance, which significantly facilitates the process of gas diffusion. Constant electricity price increases, as well as the general process of anthropopression, have triggered, among other things, a search for newer technologies of water recovery. Thus it was about devising technologies exploiting renewable energy sources, mainly wind, and exploiting the power of nature itself in the process of rehabilitation to a greater extent than before. The next direction was to devise technologies initiating and stimulating processes of the activation of new food chains (being started also in the hypolimnion), which resulted in removal of a superabundance of organic matter from the most endangered lake areas. This was the reason for research in two primary directions. At the first stage researchers strived to increase the effectiveness of gas exchange taking place during aeration (where hydrogen sulphide was replaced with oxygen). At the second stage, in turn, researchers made efforts to exploit wind energy in the aeration process. Both the above-mentioned directions were explored in the Institute of Agricultural Engineering in Poznan University of Life Sciences (Podsiadłowski and Dziudziel 2005).

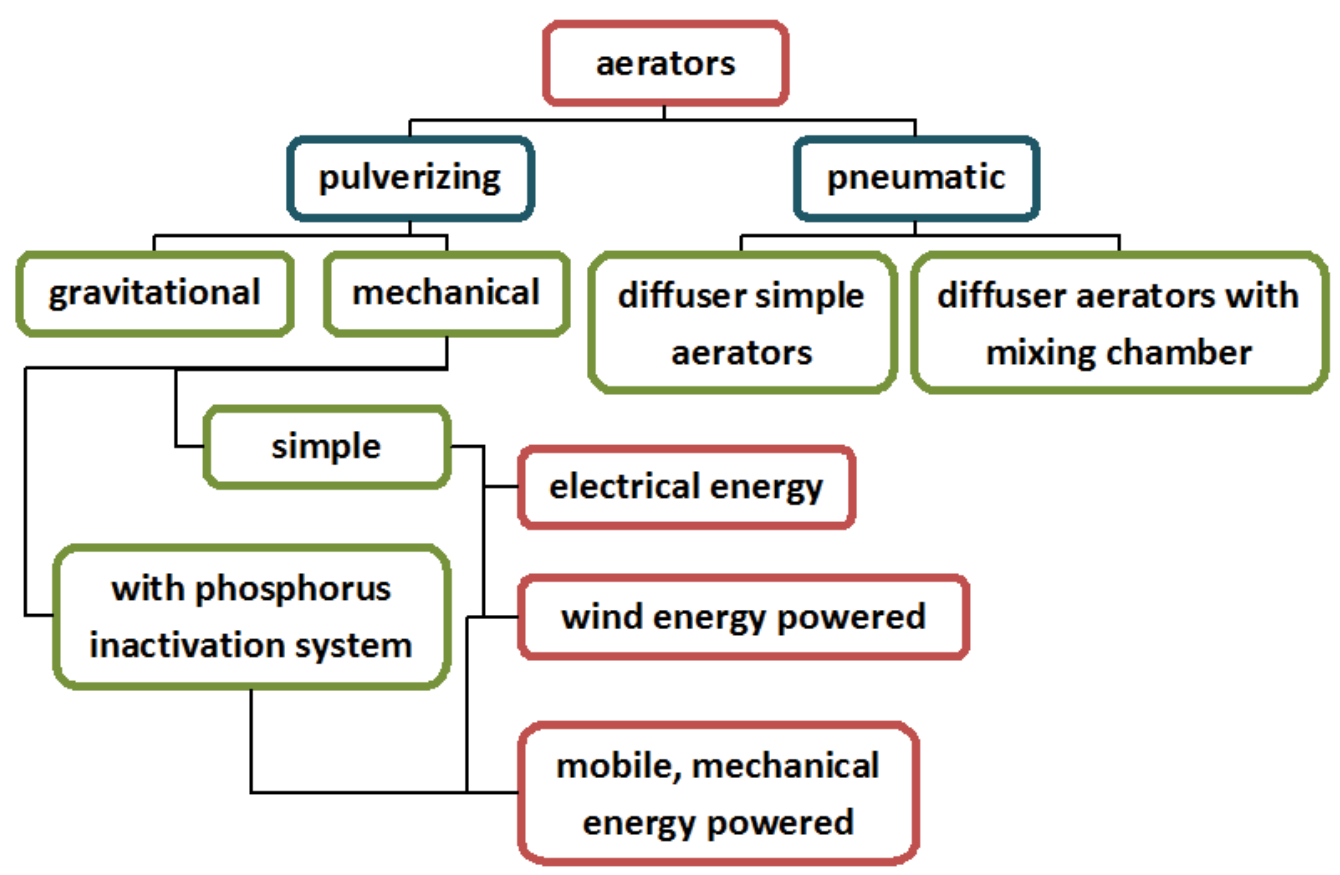

Fig. 1. Division of aerators 


\section{Methods}

The working principle of the aerator is that energy obtained by means of a Savonius wind turbine is used mainly for gas diffusion - hydrogen sulphide is released, which results in total saturation of the hypolimnion waters, which are thereafter oxygenated. It allows an intense aeration zone to be created (Fig. 2). As the results of our research show (confirmed also by Konieczny (2004)), the zone comparatively frequently undergoes translocation resulting from natural tides of lake water that occur during wind.

In the deep lake conditions (Fig. 2) of defined stratification, an oxygenated water zone develops in the hypolimnion layer allowing oxygenation of compounds. Pulverizing aerators (Fig. 4), which are powered with wind energy, provide the near-bottom layer of lakes with oxygen, thus making it possible to inactivate phosphorus that is released during lakebed emissions, because phosphorus is a biogenic element (Kentzer 2001; Dunalska 2009). Since 2003, pulver-

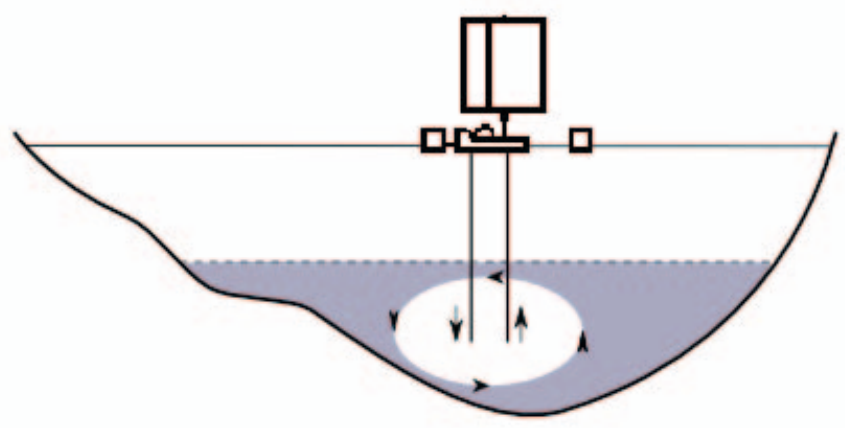

Fig. 2. The pulverizing aerator in deep lake conditions

izing aerators have therefore been equipped with a phosphorus inactivation system, which allows coagulant to be administered during the aeration process (Fig. 3).

In the years 2008-2010, the researchers were making attempts to increase the general efficiency of water flow in the aerator and to improve water pulver-

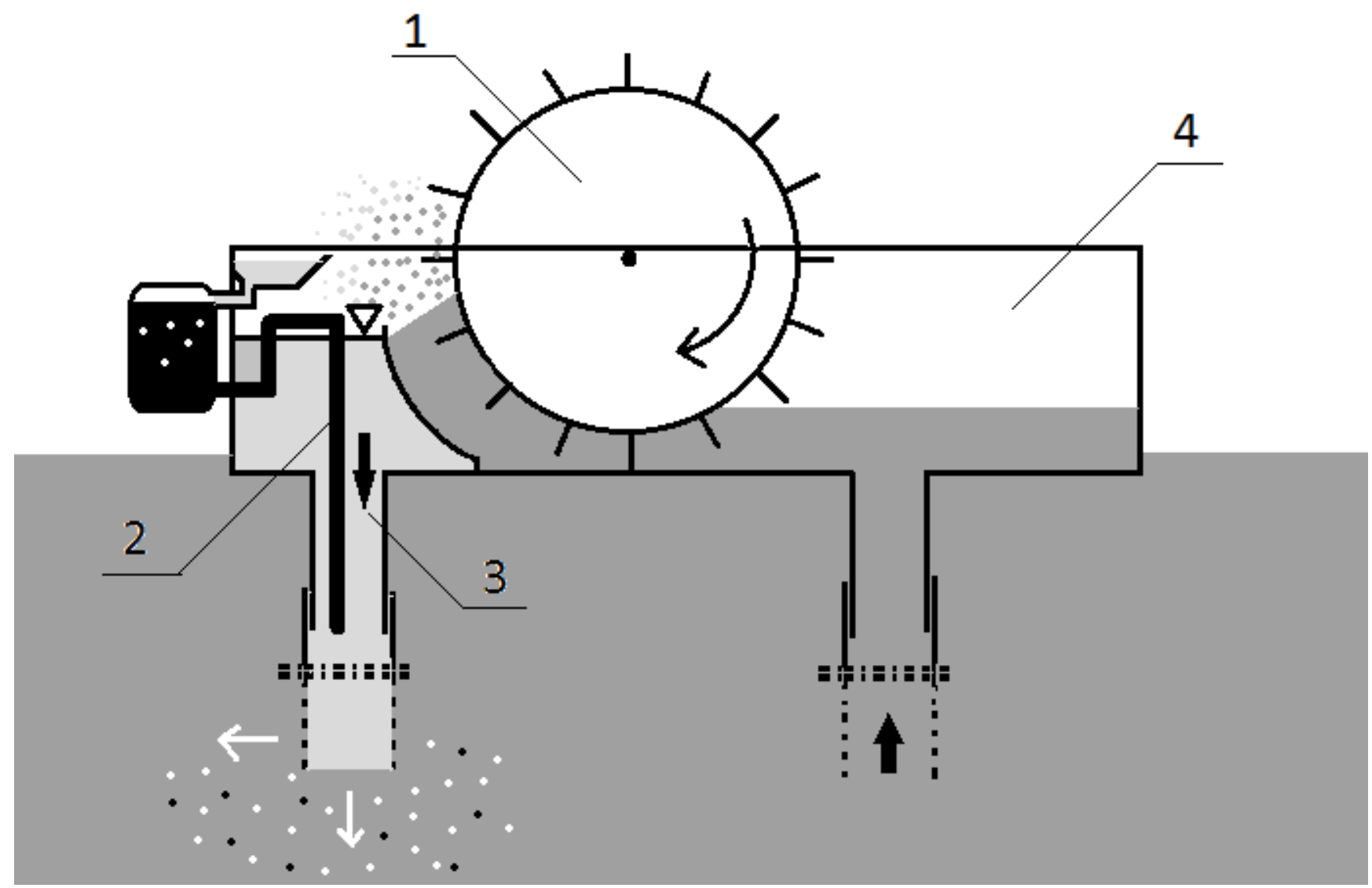

Fig. 3. Diagram of the pulverizing aerator with a phosphorus inactivation system: 1 - pulverizer, 2 - dispenser of preparation (coagulant), 3 - pressing section, 4 - suction section 


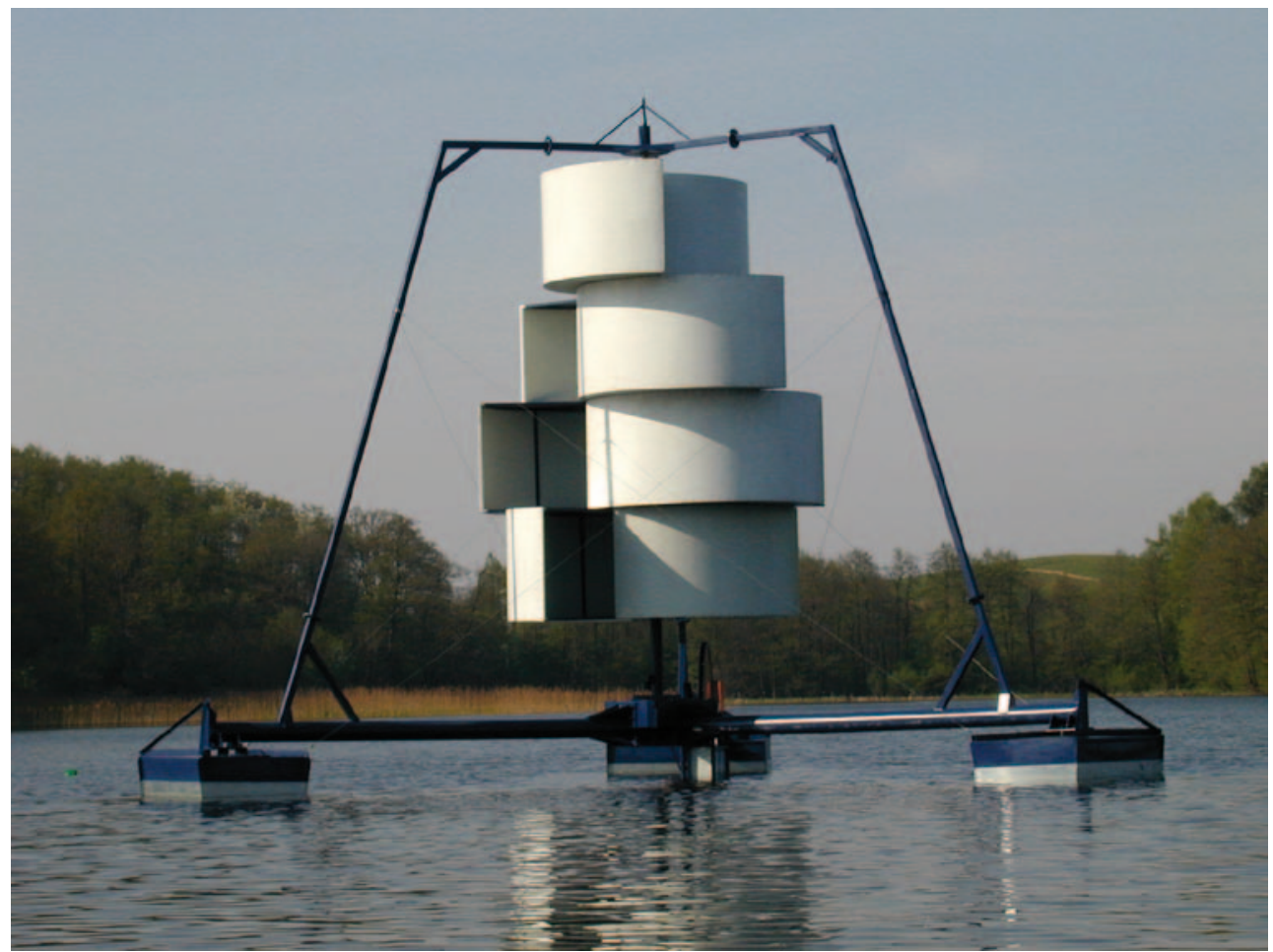

Fig. 4. Pulverizing aerator

ization (spraying). Another improvement concerned the system of administration of coagulants (sulphate, iron chloride or magnesium chloride) to oxygenated water, which returns to the hypolimnion. This paper is devoted to the evaluation of the effectiveness of pulverizing aeration carried out in conditions of a typical postglacial lake.

\section{Results}

The general aim of the study was to define the effectiveness of pulverizing aeration combined with phosphorus inactivation in the water of Lake Panieńskie. The lake is located near Pełczyce, Poland $\left(53^{\circ} 02.7^{\prime} \mathrm{N}, 15^{\circ} 17.9^{\prime} \mathrm{E}\right)$ with an area of approximately 22.2 ha, a volume of $1712900 \mathrm{~m}^{3}$, a maximum depth of $16.6 \mathrm{~m}$ and an average depth of $7.7 \mathrm{~m}$. It is a typical postglacial lake in the Myślibórz Lakeland (Fig. 5).

Due to its location, Lake Panieńskie underwent intense anthropopression, being a direct receiver of municipal and agricultural sewage in the past. This resulted in a significant deterioration in the condition of the lake water (phytoplankton domination). Lake eutrophication was quickened by, among others, algal blooms including cyanotic, and abatement

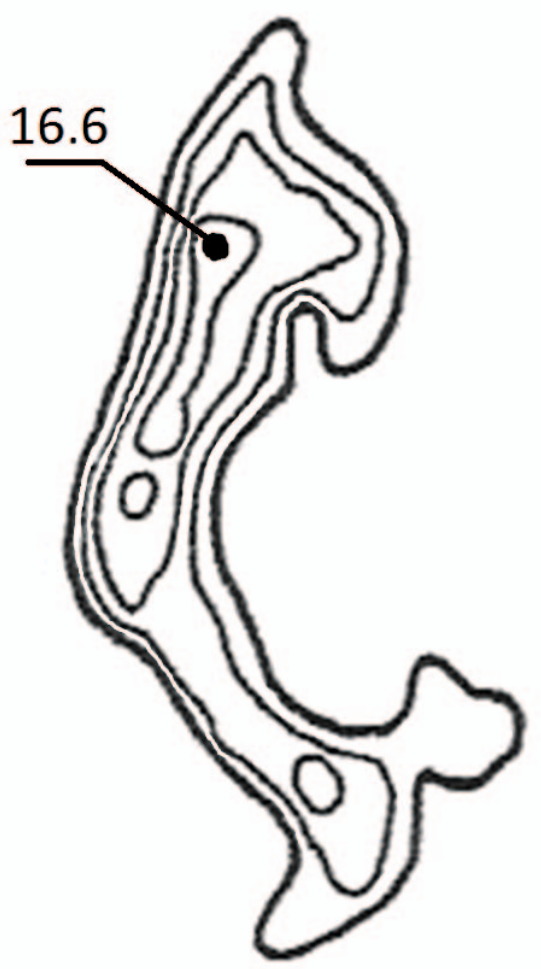

Fig. 5. Bathymetry map of Lake Panieńskie 
of immersed vegetation from the coastal area - the littoral zone. In Lake Panieńskie bed deposits, it is mineral fraction which constitutes an integral component. Organic matter in the lake's deepest spot makes up around 16\%, whereas in the littoral zone it is approximately $5.5 \%$. Regulation of water and sewage economy in the city allowed lake rehabilitation proceedings to be undertaken, which covered th following:

- oxygenation of the near-bottom layer of the lake (the hypolimnion) within the lake's deepest spot

- phosphorus inactivation in the hypolimnion

Research involved the analysis of the work of the pulverizing aerator, as well as the effect of aeration on the condition of Lake Panieńskie's water.

Research was carried out at a wind speed which fluctuated from 2.19 to $5.49 \mathrm{~m} \mathrm{~s}^{-1}$. The speed was measured with a Kestrel 3000 anemometer at the height of $3.60 \mathrm{~m}$ (measured from the water surface), which equalled half the height of the wind turbine. In turn, the level of water oxygenation was measured by means of a WTW Oxi dissolved oxygen sensor.

The influence of wind speed on oxygenation of water in the pulverizer, which is simultaneously the main index of the efficiency of the process, was already discussed in a previous paper (Podsiadłowski et al. 2005). So far, we have lacked accurate data concerning the efficiency of pulverizing aeration at different levels of wind speed. Obtaining these data proved to be important, especially with regard to the installation of the phosphorus inactivation system in the pulver-

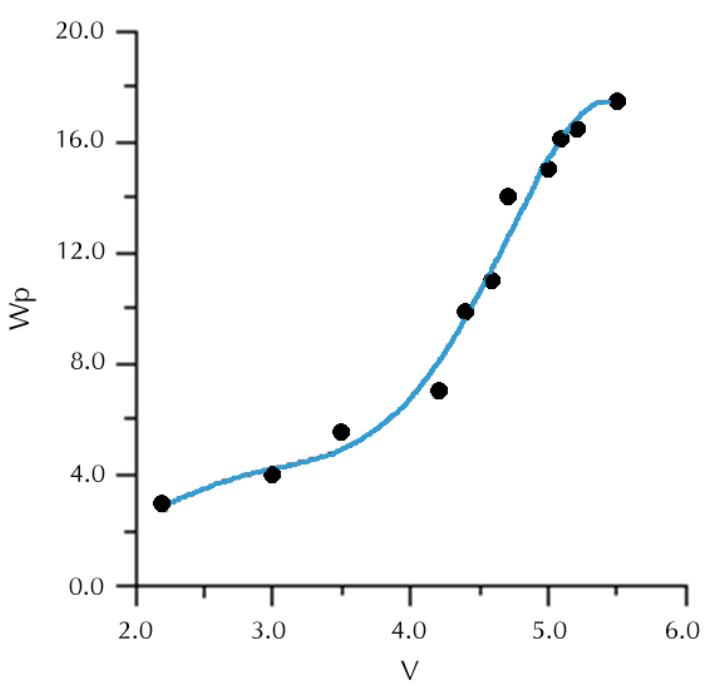

Fig. 6. Influence of wind speed $\mathrm{V}\left(\mathrm{m} \mathrm{s}^{-1}\right)$ on pulverizing aeration efficiency Wp $\left(\mathrm{dm}^{3} \mathrm{~s}^{-1}\right)$ izing aerator. Pulverizing aeration efficiency had been defined through the establishment of the average efficiency of water flow through the pulverizer suction hose. What follows from the correlation presented in Figure 6 is that pulverizing aeration efficiency considerably increases along with wind speed escalation, with the most intense increase that has been recorded so far fluctuating from 4.21 to $5.21 \mathrm{~m} \mathrm{~s}^{-1}$. The increase follows from the self-sealing of the pulverizer rotor at higher speeds of water flow (Konieczny 2004). In turn at higher levels of wind speed (over $4.21 \mathrm{~m} \mathrm{~s}^{-1}$ ), researchers observed the choking phenomenon in aeration efficiency due to constrained flow efficiency of suction hoses, which was constructionally adjusted to the range of wind speed characterized by high frequency $\left(2.99-5.00 \mathrm{~m} \mathrm{~s}^{-1}\right)$.

The phosphorus inactivation system in the pulverizing aerator was designed in a way that enabled correlation of the administration of the preparation with aeration efficiency (Fig. 3). On the one hand, it was aimed at the administration of the preparation to oxygenated water, and on the other, at the avoidance of administration of the preparation while lacking pulverization and water flow. The other concern was to obtain comparative constructional simplicity, which would guarantee good dependability of the system in lake conditions. The efficiency dependence (Wk) of preparation (coagulant) administration on the average wind speed $(\mathrm{Vh})$, as presented in Figure 7, indicates significant correlation within the scope of the

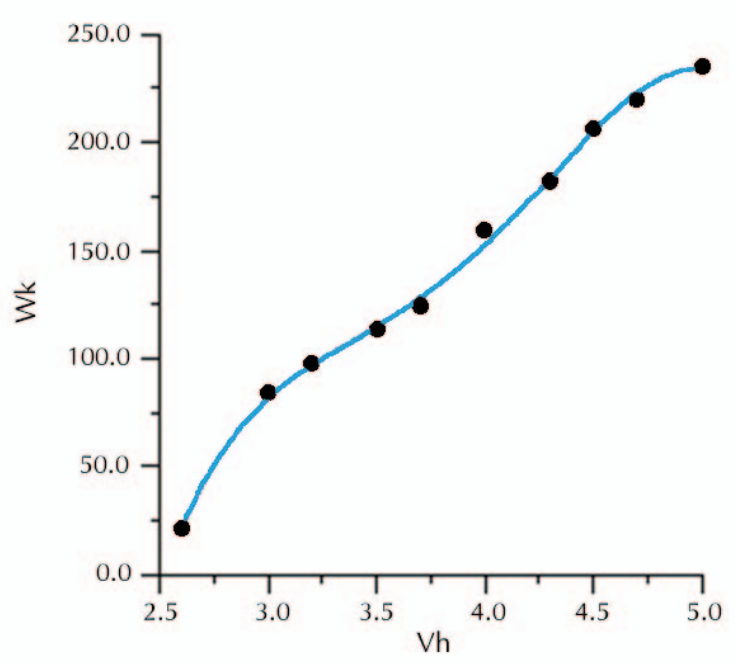

Fig. 7. Influence of average wind speed $\mathrm{Vh}\left(\mathrm{m} \mathrm{s}^{-1}\right)$ on the dispenser of coagulant efficiency, Wk $\left(\mathrm{g} \mathrm{h}^{-1}\right)$ 
conducted research. Medium wind speed (2.99-3.99 $\mathrm{m} \mathrm{s}^{-1}$ ) triggers a dosage of around $100 \mathrm{~g}$ of preparation per hour of the pulverizing aerator's work. It was assumed that such an amount is enough to precipitate phosphates in the Panieńskie lake aeration area. The commencement of the rehabilitation process in 2010 significantly affected the lake's condition, and the first visible result was the increase in water transparency, which was measured with the Secchi disk (Fig. 8).

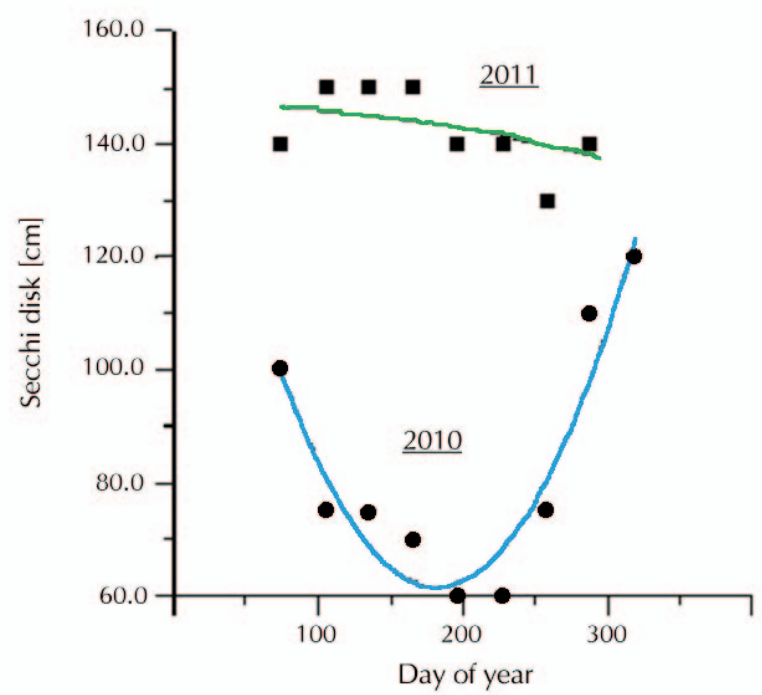

Fig. 8. Changeability of the Secchi disk visibility on Lake Panieńskie in 2010-2011

Water transparency increase is beneficial for the lake due to the fact that it leads to gradual infestation of a lakebed by underwater vegetation, which stabilizes all the changes taking place in the ecosystem. In some cases, where a rehabilitated lake is deprived of macrophytes that have been immersed in water for a number of years, it is necessary to reintroduce them, since seeds or their other reproduction organs did not survive in sediments. Spot planting in lakes enables them to develop, frequently through vegetative spread, in the entire littoral zone. During the period following the plants' introduction, they require special protection, otherwise they will be destroyed by water birds, fish, waves etc. As our studies have shown, Lake Panieńskie does not require additional provision of immersed plants yet, since it has been found that they develop on their own as a result of solar energy reaching the bottom of the littoral zone. Application of the pulverizing aerator over the deepest spot of Lake Panieńskie also caused crucial changes in oxygenation of the near-bottom layer (Fig. 9), which allowed food chains to be created, located around the lakebed.

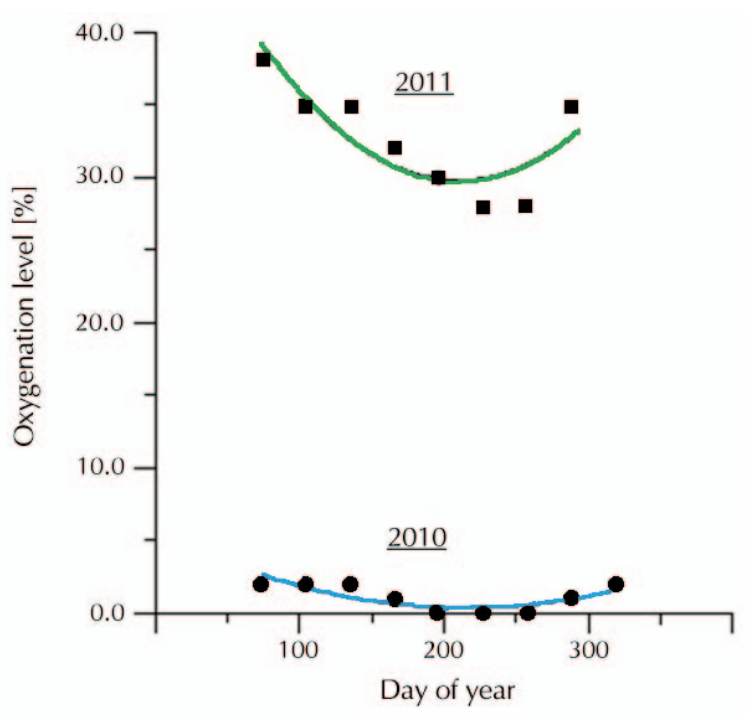

Fig. 9. Changeability of oxygenation level of the near-bottom layer of water in the deepest spot of Lake Panieńskie in 2010-2011

The pulverizing aerator's activity changed directly not only the near-bottom layer of the lake (it is important for the development of macrozoobenthos and permanent phosphorus mineralization) but also the entire hypolimnion layer (Fig. 10).

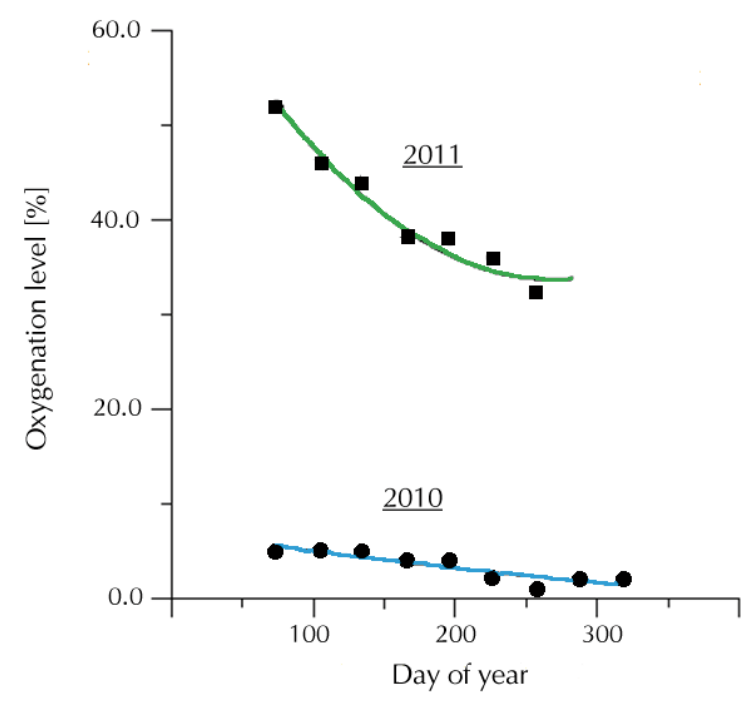

Fig. 10. Changeability of the hypolimnion water oxygenation level in the deepest spot of Lake Panieńskie in 2010-2011 
The results of research prove the good efficiency of phosphorus inactivation treatments, which is supported by the phosphorus inactivation system installed in the stationary pulverizing aerator (Fig. 11). Because ice meltdown was directly followed by administration of coagulant (by means of the aerator), it allowed primary production of biomass, i.e., bloom of diatoms (Pennateae), to be constrained in early spring. Further work of the aerator allowed residential phosphorus availability to be constrained, which allowed massive blooms of phytoplankton (including cyanobacteria) to be avoided and relatively good water transparency to be maintained.

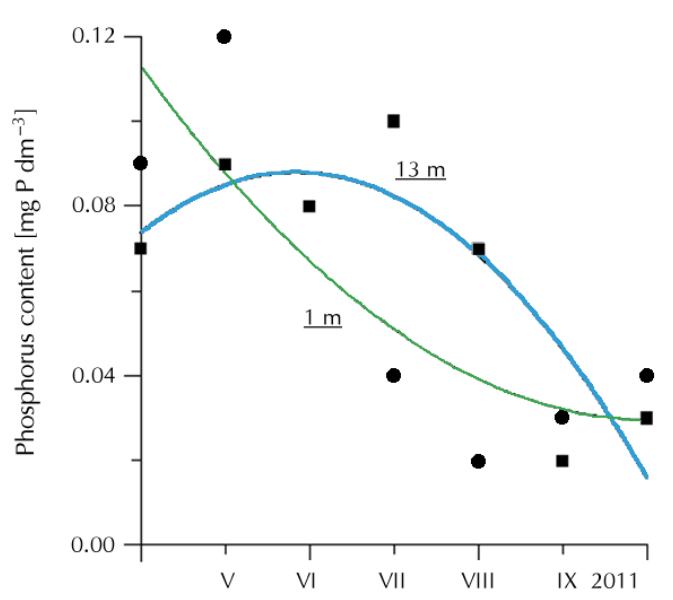

Fig. 11. Changeability of phosphorus content in Lake Panieńskie waters in 2011 summer half-year

\section{Conclusions}

The conducted study and observations make it possible to draw the following conclusions:

1. Pulverizing aeration efficiency visibly depends on wind speed, fluctuating from 0.3 to $1.80 \mathrm{~m} \mathrm{~s}^{-1}$.

2. The phosphorus inactivation system which was proposed for the pulverizing aerator measures up to expectations. It allows coagulant to be administered to water that has already been oxygenated and simultaneously prevents energy load on the wind turbine.
3. Coagulant dosage efficiency visibly depends on wind speed (from around 20 to $230 \mathrm{~g} \mathrm{~h}^{-1}$ ), which enables permanent phosphorus inactivation.

4. Pulverizing aeration improves oxygen conditions in the deepest spot of the lake, allowing activation of the lake rehabilitation process.

\section{References}

Dunalska J., 2009, Zmienność form węgla organicznego w zróżnicowanych troficznie ekosystemach jeziorowych (The variability of the forms of organic carbon in trophically diverse lake ecosystems), Wyd. UWM, Olsztyn, p. 116 (in Polish, English summary).

Kentzer A., 2001, Fosfor i jego biologiczne dostępne frakcje w osadach jezior o różnej trofii (Phosphorus and its biologically available fractions in sediments of lakes of different trophic status), Wyd. UMK, Toruń, p. 111 (in Polish).

Konieczny R., 2004, Aeracja pulweryzacyjna w warunkach Jeziora Barlinieckiego (Pulverizing aeration under conditions of Bralineckie Lake), Woda-Środowisko-Obszary Wiejskie 4(12): 291-301 (in Polish, English summary).

Lossow K., Gawrońska H., Jaszczułt R., 1998, Attempts to use wind energy for artificial destratification of Lake Starodworskie, Pol. J. Environ. Stud. 7(4): 221-227.

Podsiadłowski S., 2001, Aeracja jezior strefy umiarkowanej (Aeration of lakes in the temperate zone), Ekopartner 6(116): 15-16 (in Polish).

Podsiadłowski S., Dziudziel J., 2005, Beluftung der Seen gemassigter Zone (Aeration of lakes in the temperate zone), Proc. of the Conference „Intuicja i architektura” (Intuition and architecture), Poznań, 24 October 2003, Wyd. PPozn., Poznań: 571-580 (in German).

Podsiadłowski S., Piechnik L., Podsiadłowski W., 2005, Efektywność aeracji pulweryzacyjnej Jeziora Jaroszewskiego (The effectiveness of pulverizing aeration on Jaroszewskie Lake), Proc. of the Conference „Rekultywacja środowisk zdegradowanych", Lublin-Janów Lubelski-Jeziórko-Machów-Piaseczno, 30-31 August 2005, Wyd. ARLub, Lublin: 61-68.

Soszka H., Cydzik D., Czajka J., 2003, Jeziora (Lakes), [in:] Raport: Stan środowiska w Polsce w latach 1996-2001 (Report: The state of environment in Poland in 19962001), Biblioteka Monitoringu Środowiska, IOŚ, Warszawa, p. 111-117. 